\title{
Cigarette smoking and duodenal ulcer
}

\author{
D H HULL AND P J BEALE
}

From the Medical Division, Princess Alexandra Hospital, Wroughton, RAF Wroughton, Swindon, Wiltshire

SUMmaRY Tobacco smoking delays healing of gastric ulcer and may influence duodenal ulceration. Seventy men, all cigarette smokers, were found to have duodenal ulceration at endoscopy. All were advised to stop smoking and received a three-month course of cimetidine. Endoscopy was repeated at three months $(n=63)$ and at six months $(n=56)$. At three months most $(79 \%)$ patients showed ulcer healing and there was no difference between men who had and had not stopped smoking. At six months, however, a higher proportion $(61 \%$ vs $28 \%, \mathrm{p}<0.05)$ of smokers $(n=38)$ than ex-smokers $(n=18)$ had duodenal ulceration. This difference reflected a combination of increased ulcer persistence and ulcer relapse. Neither cimetidine nor cigarette smoking nor ulcer healing appeared substantially to affect duodenitis and fixed deformity. We conclude that continued cigarette smoking does not prevent the powerful duodenal ulcer healing effect of cimetidine but does predispose to an increased expectation of duodenal ulceration soon after cimetidine has been stopped.

A relationship between tobacco smoking and peptic ulceration has been suspected for many years. An early retrospective survey ${ }^{1}$ found no evidence of a connection, but soon after, evidence for the association was published. ${ }^{2}{ }^{3}$ It has been known for some years that the mortality of peptic ulcer is higher in smokers than in non-smokers. ${ }^{4}$ Doll et al found that patients with duodenal ulcers and with gastric ulcers were more often smokers than were eupeptic controls. Ulcer patients smoked mainly cigarettes; non-ulcer controls who did smoke were less often cigarette smokers and more often preferred pipes or cigars.

Gray $^{3}$ found that stopping smoking led to rapid improvement in the symptoms of peptic ulceration, and since then there have been several studies affirming the adverse effect on healing of continued smoking. This was shown first for gastric ulcer ${ }^{6}$ and later for duodenal ulcer. ${ }^{7-10}$ Objective benefits from stopping smoking have rarely been assessed. ${ }^{11}$

The benefits of continued abstinence from tobacco smoking once duodenal ulcer has healed are even less certain. There is some evidence that continued cigarette smoking predisposes to relapse of duodenal ulcer, ${ }^{12}$ and Korman et al ${ }^{13}$ called for attention to this problem in future trials.

We have studied the outcome of duodenal ulcer

Address for correspondence: Group Captain D H Hull, RAF, RAF Central Medical Establishment, Kelvin House, Cleveland Street, London W1P 6AU. Received for publication 25 February 1985 and duodenitis in men treated with cimetidine, some of whom succeeded in giving up cigarette smoking.

\section{Methods}

\section{PATIENTS}

Seventy men entered the study. All were cigarette smokers (average 18 cigarettes per day, range 3-40). Their average age at entry was 31 years (range 19-62 years). All but four were active duty servicemen (Royal Air Force or Army). All gave a history of dyspepsia suggestive of peptic ulcer, of average duration 6.15 years (range two weeks to 33 years).

Initial evaluation included fibre optic gastroduodenoscopy which confirmed duodenal and/or pyloric canal ulceration in every case. Ulcer size was graded as small, medium, or large. A few patients had two or even three ulcers, so that the number of ulcers exceeded the number of patients. Presence or absence of duodenitis was noted, and whether it was localised or generalised. Duodenitis was classified as injected, 'pepper and salt', or aphthous, and graded as minimal, mild, moderate, or severe, solely on endoscopic appearances. No duodenal biopsies were taken. Note was also made of contact bleeding. Duodenal fixed deformity, when present, was graded as minor or major.

All patients were given a three month course of oral cimetidine tablets, initially $1 \mathrm{~g}$ daily in divided doses $(200 \mathrm{mg}$ three times daily and $400 \mathrm{mg}$ on 
retiring to bed). After six weeks the daytime tablets were stopped but the evening dose of $400 \mathrm{mg}$ was continued till review at three months. Endoscopy was repeated at three months and at six months. Irrespective of the findings at three months, no further cimetidine or other histamine $\mathrm{H} 2$ antagonist was prescribed. Patients were allowed to use antacids to relieve symptoms if necessary.

At the start of treatment and at three months, all patients were strongly advised to stop cigarette smoking completely and permanently, and not to smoke other forms of tobacco. At three months those who had stopped smoking completely at least six weeks previously, and had remained abstinent, were classified as ex-smokers at three months; all others were designated smokers. At six months, all those who had stopped smoking at least six weeks previously, and had remained abstinent, were classified as ex-smokers at six months. All others were classified as smokers.

Comparisons were made using standard statistical methods.

\section{Results}

Sixty three patients were followed up at three months and of these, $50(79 \%)$ showed ulcer healing. Unhealed ulcers were no commoner $(19 \%)$ in the 47 smokers than in the 16 ex-smokers $(25 \%-$ $\mathrm{p}=\mathrm{NS}$ ). (Table 1).

Fifty six patients* were followed up at six months. Thirty eight were smokers of whom 35 smoked throughout the study and three resumed the habit after their three month review. Twenty three smokers at six months $(61 \%)$ had duodenal ulcers. Sixteen of these had shown ulcer healing at three months and had relapsed; the remaining seven had had duodenal ulcers at three months (duodenal ulcer persistence). Of nine smokers with duodenal ulcers at three months, one was lost to follow up; of the remaining eight, only one healed by six months.

Eighteen patients were ex-smokers at six months; 11 had been ex-smokers at three months also, while the remaining seven stopped smoking after their three month review. Only five $(28 \%)$ of ex-smokers had duodenal ulcers at six months. This difference in duodenal ulcers between smokers and ex-smokers at six months is significant $(p<0.05)$. The five exsmokers with duodenal ulcers at six months had all shown ulcer healing at three months. Four exsmokers who had duodenal ulcers at three months

\footnotetext{
* Seven patients were lost to follow up in the first part of the study and seven more in the second part. Two left the armed forces and were unavailable; seven were posted away on duty and five missed follow up because of administrative omissions. Of the seven lost in the second part of the study, five were smokers, four of whose duodenal ulcers had healed at three months; two were ex-smokers, both with healed duodenal ulcers.
}

Table 1 Endoscopic outcome at each stage of study

\begin{tabular}{|c|c|c|c|}
\hline & $\begin{array}{l}\text { Entry } \\
\quad \text { With } \\
\text { no } D U(\%)\end{array}$ & $\begin{array}{c}3 \text { months } \\
\quad \text { With } \\
\text { no } D U(\%)\end{array}$ & $\begin{array}{c}6 \text { months } \\
\quad \text { With } \\
\text { no } D U(\%)\end{array}$ \\
\hline Smokers & $7070(100 \%)$ & $47 \quad 9(19 \%)$ & $3823(61 \%)$ \\
\hline Ex-smokers & Nil Nil & $164(25 \%)$ & $185(28 \%)^{*}$ \\
\hline Totals & 7070 & $6313(21 \%)$ & $56 \quad 28(50 \%)$ \\
\hline
\end{tabular}

* Smokers and ex-smokers differ: $p<0.05$

all healed by six months. In this respect (spontaneous healing rate in second three months) they differed significantly $(p<0.01)$ from the smokers (seven of eight unhealed, vs).

Table 2 shows the relapse rate of the subset of 50 patients whose duodenal ulcers had healed at three months, categorised by smoking status. Relapse at six months was more common $(53 \%)$ in smokers than in ex-smokers $(36 \%)$; this difference does not attain significance $(0.2<\mathrm{p}<0.3)$, the numbers involved being rather small. The significant disadvantage in duodenal ulcer experience of smokers compared with ex-smokers at six months emerges when duodenal ulcer relapse and duodenal ulcer persistence are combined (Table 1).

Smokers were compared with ex-smokers in respect of their initial characteristics at entry to the study, in an attempt to detect any important differences between the groups which might have biased results. Average age, length of history, daily cigarette consumption, number and size of ulcers showed no significant initial differences between groups either at three or six months. Initial duodenal fixed deformity, contact bleeding and duodenitis (type, severity, extent) were statistically indistinguishable in those who would be smokers and ex-smokers at three months. At six months, however, ex-smokers were found originally to have shown a different distribution of type of duodenitis (more 'pepper and salt' and less aphthous), more localised and less generalised duodenitis, and less severe duodenal fixed deformity, than the smokers. Levels

Table 2 Relapse after healing. Six month outcome of patients healed at three months $(n=50)$

\begin{tabular}{|c|c|c|c|}
\hline & & No & With $D U(\%)$ \\
\hline $\begin{array}{r}\text { Smokers } \\
\text { at } 6 / 12\end{array}$ & $\left\{\begin{array}{l}\text { Smokers throughout } \\
\text { Ex-smokers at } 3 / 12\end{array}\right.$ & $\left.\begin{array}{r}27 \\
3\end{array}\right\} 30$ & $\left.\begin{array}{r}15 \\
1\end{array}\right\} 16(53 \%)$ \\
\hline $\begin{array}{l}\text { Ex-smokers } \\
\text { at } 6 / 12\end{array}$ & $\left\{\begin{array}{l}\text { Smokers at } 3 / 12 \\
\text { Ex-smokers throughout }\end{array}\right.$ & $\left.\begin{array}{l}7 \\
t \quad 7\end{array}\right\} 14$ & $\left.\begin{array}{l}2 \\
3\end{array}\right\} 5(36 \%)$ \\
\hline $\begin{array}{l}\text { Lost to } \\
\text { follow up }\end{array}$ & $\left\{\begin{array}{l}\text { Smokers at } 3 / 12 \\
\text { Ex-smokers at } 3 / 12\end{array}\right.$ & $\left.\begin{array}{l}4 \\
2\end{array}\right\} 6$ & - \\
\hline Totals & & 50 & \\
\hline
\end{tabular}


of significance were low $(0 \cdot 02<\mathrm{p}<0.05)$ and in view of the large number of comparisons, the differences should probably not be considered important.

Apart, therefore, from these details, those who would stop smoking by three months or by six months could not be distinguished initially from those who would continue to smoke at these dates.

At diagnosis, several patients had more than one ulcer, so that numbers of ulcers (83) exceeded numbers of patients (70). Both at three months and at six months there was a tendency, not reaching significance, for ulcers to be smaller and less often multiple than initially, both amongst smokers and ex-smokers.

Presence and degree of fixed deformity altered barely at all in either group at three or six months. Less expected was the finding that the type, extent and severity of duodenitis altered very little during the study, either in smokers or ex-smokers. The severity of duodenitis showed a tendency to decline at three months, but this did not reach significance, and at six months duodenitis was as severe as at entry to the study. Neither smoking nor cimetidine nor ulcer healing affected duodenitis appreciably; it was remarkable how many patients showed unchanged or almost unchanged appearances at all three examinations. Healing of duodenal ulcers and of duodenitis is evidently independent.

\section{Discussion}

SMOKING AND RESPONSE TO CIMETIDINE

Cigarette smoking may reduce duodenal ulcer healing rate in response to medical treatment. This has been shown for placebo, ${ }^{7}{ }^{12}$ for trimipramine, ${ }^{8}$ antacids, ${ }^{13}{ }^{14}$, sulpiride, ${ }^{15}$ pirenzepine ${ }^{12}$ and carbenoxolone. ${ }^{11}$ Whether smoking interferes with healing by $\mathrm{H} 2$-receptor antagonists is less certain. Several studies have found that cimetidine ${ }^{16-19}$ and ranitidine $^{18}$ heal duodenal ulcers as effectively in smokers as in non-smokers. This concurs with our findings in the first three months of the present study. These findings have been disputed, howev$\mathrm{er}^{20}$ and a number of authors ${ }^{91012} 21$ in particular Korman and his group ${ }^{1322} 23$ have repeatedly found that duodenal ulcer healing rates are lower in cigarette smokers than in non-smokers treated with cimetidine, and the same may be true of ranitidine ${ }^{24}$ and oxmetidine. ${ }^{22} 23$

A factor that may have contributed to duodenal ulcer healing in our patients who continued to smoke was reduction in tobacco consumption. Many claimed to be smoking many less cigarettes during the treatment period. Hetzel et $a l^{23}$ found that light smoking ( $<$ nine cigarettes daily), as opposed to a larger consumption, had no adverse effects on the healing rate of duodenal ulcers in patients treated with cimetidine or ranitidine.

SMOKING AND DUODENAL ULCER POST-CIMETIDINE

(a) Duodenal ulcer relapse

The higher incidence of duodenal ulcers in smokers at the end of our study was because of a combination of duodenal ulcer relapse and duodenal ulcer persistence. Duodenal ulcer relapse may occur in as many as $50 \%$ of patients within six months of cessation of successful $\mathrm{H} 2$ receptor blockade. ${ }^{10}$ Sonnenberg and colleagues ${ }^{12}$ found that continued cigarette smoking predisposed to relapse of duodenal ulcers, but that the effect appeared to be prevented by maintenance cimetidine. Sontag et $\mathrm{l}^{25}$ found cigarette smoking to be a major factor in relapse among 370 patients with endoscopically healed duodenal ulcers; even with maintenance cimetidine, smokers relapsed at least as often as non-smokers receiving only placebo. Ex-smokers were not separately assessed. Gough et $a l^{26}$ found smoking to be highly correlated with duodenal ulcer relapse despite maintenance cimetidine or ranitidine. Korman et $a l^{22}$ found duodenal ulcer relapse after $\mathrm{H} 2$-receptor mediated healing to be earlier and commoner in cigarette smokers to a degree related to the number of cigarettes smoked daily. The published evidence therefore strongly supports the suggestion that cigarette smoking promotes relapse in patients with healed duodenal ulcers. In our study, the $53 \%$ of smokers whose ulcers had relapsed at six months compares with a relapse rate of $36 \%$ in ex-smokers; the small numbers involved mean that such a difference is not statistically significant.

\section{(b) Duodenal ulcer persistence}

There are few studies of the effects of stopping smoking on the natural course of untreated duodenal ulcers. For gastric ulcer, Doll et at found that stopping smoking led to accelerated healing. Young et al $^{11}$ reported an advantage from stopping smoking in healing duodenal ulcers in placebo treated patients. Other studies using placebo ${ }^{7} 12$ suggest reduced duodenal ulcer healing rate in smokers. An effect from stopping smoking may be hard to detect because of the infrequency with which cigarette smoking dyspeptics will abandon the habit; Sonnenberg et $\mathrm{l}^{12}$ were able to persuade only three of 66 duodenal ulcer patients to stop smoking, and one of them resumed before the study was completed. At the time of surgery for peptic ulcer, $83 \%$ of patients reviewed by Ross et al ${ }^{27}$ were cigarette smokers, few of whom stopped smoking postoperatively. Our patients' success rate $(25 \%$ ex-smokers 
at three months, $32 \%$ at six months) may be exceptional. Studies of refractory duodenal ulcers have not on the whole incriminated cigarette smoking; Bardhan, ${ }^{28}$ for example, found no difference in smoking habits between those whose duodenal ulcers resisted or responded to treatment, but more than three quarters of both groups smoked. Frederiksen et $a l^{2}$ who treated duodenal ulcer patients actively only when there was failure of spontaneous healing, found that a higher proportion of smokers required treatment but the difference compared with non-smokers was not significant. During a subsequent two-year follow up, active (drug) treatment was required more often in smokers than in non-smokers. The Surgeon-General, USA ${ }^{30}$ characterised the evidence that smoking retarded duodenal ulcer healing as 'suggestive'.

Our finding that all four ex-smokers showed spontaneous ulcer healing while seven of eight smokers failed to heal during the second (no treatment) three months of our study is highly significant. It may be that much of the increased duodenal ulcer morbidity in smokers is because of prolongation of ulcer duration rather than precocious relapse.

Our findings are consistent with the following conclusions: (1) Cimetidine in conventional doses heals the majority of duodenal ulcers in men within three months, and this effect is not prevented by continued cigarette smoking. (2) Three months after stopping cimetidine, men who continue cigarette smoking are more liable than ex-smokers to have duodenal ulcers due both to ulcer persistence and relapse. (3) Duodenitis, judged visually is little affected by cimetidine, by duodenal ulcer healing, by duodenal ulcer relapse, or by stopping smoking.

We are grateful to several colleagues who offered constructive criticism, and to Mrs Ann Julian who typed the manuscript. We thank the Medical Directors-General, Army and Royal Air Force, for approval of publication.

\section{References}

1 Barnett CW. Tobacco smoking as a factor in the production of peptic ulcer and gastric neurosis. Boston Med Surg J 1927; 197: 457-9.

2 Trowell OA. The relation of tobacco smoking to the incidence of chronic duodenal ulcer. Lancet 1934; 1: 808-9.

3 Gray I. Tobacco smoking and gastric symptoms. Ann Intern Med 1929; 3: 267-77.

4 Taylor WH, Walker V. Smoking and peptic ulceration. [Editorial]. J $R$ Soc Med 1980; 73: 159-61.
5 Doll R, Peto R. Mortality in relation to smoking: 20 years' observations on male British doctors. $\mathrm{Br}$ Med J 1976; 2: 1525-36.

6 Doll R, Avery Jones F, Pygott F. Effect of smoking on the production and maintenance of gastric and duodenal ulcers. Lancet 1958; 1: 657-62.

7 Peterson WL, Sturdevant RAL, Frankl HD et al. Healing of duodenal ulcer with an antacid regimen. $N$ Engl J Med 1977; 297: 341-5.

8 Valnes K, Wetterhus S, Ellekjaer E et al. Trimipramine in the treatment of duodenal ulcer. A multicenter, open study. Scand J Gastroenterol 1980; 15: suppl. 58: 65-70.

9 Gugler R, Rohner H-G, Kratochvil P et al. Effect of smoking on duodenal ulcer healing with cimetidine and oxmetidine. Gut 1982; 23: 866-71.

10 Korman MG, Hansky J, Merrett AC, Schmidt GT. Ranitidine in duodenal ulcer. Incidence of healing and effect of smoking. Dig Dis Sci 1982; 27: 712-5.

11 Young GP, St John DJB, Coventry DA. Treatment of duodenal ulcer with carbenoxolone sodium: a doublemasked endoscopic trial. Med J Aust 1979; 1: 2-5.

12 Sonnenberg A, Muller-Lissner SA, Vogel E et al. Predictors of duodenal ulcer healing and relapse. Gastroenterology 1981; 81: 1061-7.

13 Korman MG, Shaw RG, Hansky J et al. Influence of smoking on healing rate of duodenal ulcer in response to cimetidine or high-dose antacid. Gastroenterology 1981; 80: 1451-3.

14 Eisenmann A, Massarrat S. Factors influencing the healing rate of duodenal ulcers. [Abstract]. Acta Hepatogastroenterol (Stuttg) suppl 1980: F 3.2.

15 Lam SK, Lam KC, Lai CL et al. Treatment of duodenal ulcer with antacid and sulpiride. Gastroenterology 1979; 76: 315-22.

16 Bianchi Porro G, Petrillo M, Grossi E, Lazzaroni M. Smoking and duodenal ulcer [letter]. Gastroenterology 1980; 79: 180-1.

17 Multicentre trial. Comparison of 2 doses of cimetidine and placebo in the treatment of duodenal ulcer. Gut 1979; 20: 68-74.

18 Lee FI, Fielding JD, Costello FT. Ranitidine compared with cimetidine in the short-term healing of duodenal ulcer. Postgrad Med J 1983; 59: 88-92.

19 Marks IN, Wright JP, Denyer M, Garisch JAM, Lucke W. Comparison of sucralfate with cimetidine in the short-term treatment of chronic peptic ulcers. $S A f r$ Med J 1980; 57: 567-73.

20 Elashoff JD, Grossman MI. Smoking and duodenal ulcer [letter]. Gastroenterology 1980; 79: 181.

21 Lam SK, Koo J. Accurate prediction of duodenal-ulcer healing rate by discriminant analysis. Gastroenterology 1983; 85: 403-12.

22 Korman MG, Hansky J, Eaves ER, Schmidt GT. Influence of cigarette smoking on healing and relapse in duodenal ulcer disease. Gastroenterology 1983; 85: 871-4.

23 Hetzel DJ, Korman MG, Hansky J et al. The influence of smoking on the healing of duodenal ulcer treated with oxmetidine or cimetidine. Aust N Z J Med 1983; 13: $587-90$.

24 Korman MG, Hansky J, Merrett AC, Schmidt GT. 
Ranitidine in duodenal ulcer. Incidence of healing and effect of smoking. Dig Dis Sci 1982; NS 27: 712-5.

25 Sontag S, Graham DY, Belsito A et al. Cimetidine, cigarette smoking, and recurrence of duodenal ulcer. $N$ Engl J Med 1984; 311: 689-93.

26 Gough KR, Korman MG, Bardhan KD et al. Ranitidine and cimetidine in prevention of duodenal ulcer relapse. Lancet 1984; 2: 659-62.

27 Ross AHMcL, Smith MA, Anderson JR, Small WP. Late mortality after surgery for peptic ulcer. $N$ Engl $J$
Med 1982; 307: 519-22.

28 Bardhan KD. Refractory duodenal ulcer. Gut 1984; 25 : 711-7.

29 Frederiksen H-JB, Matzen P, Madsen P et al. Spontaneous healing of duodenal ulcers. Scand $J$ Gastroenterol 1984; 19: 417-21.

30 US Public Health Service. Smoking and health. A report of the Surgeon General: 1979. US Department of Health, Education and Welfare. DHEW Publication No (PHS) 79 - 50066: 9-3 - 9-21. 